\title{
ASSISTÊNCIA SOCIAL AOS PRESOS: UMA OPÇÃO À IMPOSSSIBILIDADE DO EXERCÍCIO DO DIREITO AO TRABALHO
}

JefFerson Aparecido Dias

Doutor em Direitos Humanos e Desenvolvimento pela Universidade Pablo de Olavide de Sevilha (Espanha), Procurador da República de Marília e Procurador Regional dos Direitos do Cidadão Substituto do Estado de São Paulo, Professor convidado do Mestrado em Direitos Humanos, Desenvolvimento e Interculturalidade da Universidade Pablo de Olavide e Professor permanente do Mestrado em Direito da Universidade de Marília (UNIMAR).

Fernanda Mesquita Serva Doutoranda em Educação na UNESP-Marília e Mestre em Direito pela Universidade de Marília (UNIMAR), Doutoranda na UNESP, campus Marília, e Pró-Reitora de Ação Comunitária da Universidade de Marília (UNIMAR).

\section{Resumo}

Ao contrário do que sentencia o ditado popular, de que o direito de cada um termina onde começa o do outro, a realidade é que o direito de cada cidadão termina onde termina o direito do outro. Isso porque os direitos das pessoas são convergentes e não contraditórios. A partir dessa nova premissa, o presente artigo pretende sustentar a possibilidade de as pessoas presas pela prática de crimes receberem o benefício assistencial previsto no art. 203 da Constituição e regulamentado pela Lei no 8.742/1993, desde que estejam preenchidos os requisitos previstos na lei. Além disso, o objetivo é demonstrar o equívoco das decisões que negam o referido benefício assistencial sob o argumento de que os presos já estão amparados pelo Estado, a partir da análise de relatórios que demonstram a situação caótica na qual se encontram os presídios e unidades prisionais no Brasil.

\section{Palavras-chave}

Assistência social; Execução penal; Benefício assistencial; Preso.

\section{Abstract}

Contrary to what states the popular saying, that the right of each individual ends where the other begins, in reality the right of every citizen ends where it ends the right of 
the other. This is because the people's rights are converging and not contradictory. From this new premise, this article aims to sustain the possibility of people arrested for crimes to receive welfare provided for in art. 203 of the Constitution and regulated by Law No. 8,742 / 1993, provided that all requirements are fulfilled the law. In addition, the objective is to demonstrate the misconception of the decisions that deny such welfare benefit on the grounds that prisoners are already supported by the state, from the analysis of reports showing the chaotic situation in which prisons and correctional facilities in Brazil are.

\section{Key words}

Social assistance; Penal execution; Welfare; Arrested.

\section{Introdução}

Um dos temas mais discutidos na atualidade diz respeito ao tratamento que deve ser dispensado às pessoas que se encontram privadas de sua liberdade em razão de condenaçóes decorrentes da prática de crimes.

Afinal, seria justo que um Estado que não consegue garantir direitos para todos os seus cidadáos dispensar recursos para atender às necessidades daquelas pessoas que cometeram crimes? Ou o correto seria tratar de forma diferenciada aqueles cidadãos em conflito com lei, restringindo-lhes os direitos?

$\mathrm{Na}$ verdade, a nossa evolução jurídico-histórica ainda não nos permitiu perceber que, ao definirmos os direitos de um cidadão, estamos definindo os direitos de todos os cidadãos. Assim, se definimos que um cidadão tem determinados direitos, que estão sujeitos a certas restriçóes em condiçóes específicas, por ter a norma, em tese, conceitos gerais e abstratos, estamos definindo quais serão os direitos de todos os cidadãos e quais as restriçóes a que tais direitos estão sujeitos.

Dessa forma, a máxima popular de que o direito de um termina onde começa o direito do outro, na verdade, está equivocada, pois o direito de cada um termina exatamente onde termina o direito do outro. Afinal, os direitos de cada um não são conflitantes, mas sim convergentes com o direito do outro.

A partir dessas premissas, o presente artigo pretende analisar o cabimento do benefício assistencial de prestação continuada, previsto na Constituição Federal e regulamentado pela Lei Orgânica da Assistência Social, às pessoas privadas de liberdade pela prática de crimes.

Antes, porém, serão apresentadas algumas considerações sobre o direito de punir do Estado e, na sequência, quais seriam os objetivos das penas aplicadas àqueles que são condenados pela prática de crimes, com destaque para o ideal de ressocialização que deve nortear o tema. 
Em seguida, será apresentado o núcleo do presente texto, que é a defesa do direito de trabalho dos presos e, por consequência, o direito do preso idoso (com 65 anos de idade ou mais) ou com deficiência de receber o benefício assistencial, nos casos em que não tiver condiçóes de trabalhar e prover a própria subsistência, ou tê-la provida por sua família.

Por fim, serão feitas algumas consideraçôes sobre aspectos práticos da concessão ou não do benefício assistencial para pessoas privadas de liberdade.

\section{0 Direito de Punir do Estado}

Segundo a concepção dos jusfilósofos, o ser humano, no início de sua existência, vivia no que se convencionou chamar de Estado da Natureza e, nessa situação, tinha liberdade plena para realizar o que bem entendesse.

O problema é que um ser humano dotado de tal liberdade plena, ao se deparar com outro ser humano com a mesma liberdade, não tinha a quem recorrer, prevalecendo a vontade do mais forte. Assim, nas palavras de Hobbes, o "homem era um lobo para o homem".

Para que sua liberdade fosse garantida, segundo os contratualistas, o ser humano optou por abrir mão de parte de sua liberdade em favor de um ente superior que, em troca, garantiria o restante de sua liberdade. Assim, nasce o Estado que, em detrimento de restringir a liberdade de cada um, tem como papel garantir as liberdades de $\operatorname{todos}^{1}$ :

Fatigados de só viver em meio a temores e de encontrar inimigos em toda parte, cansados de uma liberdade cuja incerteza de conservá-la tornava inútil, sacrificaram uma parte dela para usufruir do restante com mais segurança. A soma dessas partes de liberdade, assim sacrificadas ao bem geral, constitui a soberania da nação; e aquele que foi encarregado pelas leis como depositário dessas liberdades e dos trabalhos de administração foi proclamado o soberano do povo.

A reunião de todas essas pequenas parcelas de liberdade constitui o fundamento do direito de punir. Todo exercício do poder que deste fundamento se afastar constitui abuso e não justiça; ...

Porém, esse dever de proteger a liberdade de todos, em determinados momentos, exige que o Estado impeça a prática de determinados atos e, caso eles ocorram, imponha sançóes às pessoas que o praticaram. Em casos extremos, quando o ato praticado foi definido como crime, surge a necessidade de imposição de sanções, por meio de um sistema penal, que é uma das modalidades de controle social institucionalizado ${ }^{2}$ :

1 BECCARIA, Cesare. Dos delitos e das penas. São Paulo : Martin Claret, 2000, p. 19.

2 ZAFFARONI, Eugenio Raul. PIERANGELI, José Henrique. Manual de direito penal brasileiro. Vol. 1. Parte geral. 6. ed. São Paulo : Editora Revista dos Tribunais, 2006, p. 63. 
O sistema penal é a parte do controle social que resulta institucionalizado em forma punitiva e com discurso punitivo (apesar de que frequentemente, inclusive neste âmbito, se tratou de encobrir tal discurso, ainda que de forma grosseira, dado o inquestionável da realidade punitiva).

A forma punitiva, como é evidente, se baseia na aplicação de penas àqueles que cometem condutas descritas como crimes, e tais penas, num primeiro momento, eram aplicadas a partir do princípio do taliāo, ou seja, na máxima do "olho por olho, dente por dente, sangue por sangue" 3

Esse modelo, porém, foi gradativamente alterado, sendo substituído por legislaçôes que, apesar de continuarem a considerar o direito penal uma forma de o Estado punir uma conduta tida como indesejável, passou a incorporar, também, o objetivo de prevenir a prática de delitos e, o que é mais importante para o presente artigo, ressocializar o condenado para que ele, depois de cumprida a pena, possa voltar a viver em sociedade.

Assim, depois de uma longa evolução que demandou centenas de anos, chegamos ao ponto de que a pessoa que cometeu um crime, a despeito de ter que cumprir uma pena, continua a ser considerada cidadã e, nessa qualidade, é titular de direitos.

Feitas essas reflexóes sobre o direito de punir do Estado, serão apresentadas algumas consideraçóes sobre quais são ou, pelo menos, deveriam ser os objetivos das penas aplicadas às pessoas que praticam crimes.

\section{Os Objetivos da Pena}

Se num primeiro momento a pena tinha como função precípua vingar a pessoa ofendida, retribuindo o mal praticado com outro mal, com a evoluçáo do direito penal, a pena passou a ter, também, outros objetivos, como a prevenção e a ressocialização.

Essa evolução do direito de punir do Estado é sustentada por três diferentes correntes doutrinárias ${ }^{4}$ :

As teorias absolutas (de retribuição ou retribucionistas) têm como fundamento da sanção penal a exigência de justiça: pune-se o agente porque cometeu um crime (punitur quia pecatum est)... O castigo compensa o mal e dá reparação à moral.

3 "Segundo alguns juristas e teólogos medievais e posteriores, o talião possuía um sentido puramente metafórico, indicando a proporcionalidade da pena, enquanto, para outros, o "olho por olho, dente por dente, sangue por sangue" tinha um sentido literal e assim foi aplicado entre os hebreus". ZAFFARONI, Eugenio Raul. PIERANGELI, José Henrique. Manual de direito penal brasileiro. Vol. 1. Parte geral. 6. ed. São Paulo : Editora Revista dos Tribunais, 2006, p. 159.

4 MIRABETE, Julio Fabbrini. Manual de direito penal, v. 1, Parte Geral. $6^{a}$ ed. Sáo Paulo : Atlas, 1991, p. 234-235. 


\section{(...)}

Nas teorias relativas (utilitárias ou utilitaristas) dava-se à pena um fim exclusivamente prático, em especial o de prevenção. $\mathrm{O}$ crime não seria causa da pena, mas a ocasião para ser aplicada... A pena é intimidação para todos, ao ser cominada abstratamente, e para o criminoso, ao ser imposta no caso concreto.

(...)

Já para as teorias mistas (ecléticas) fundiram-se as duas correntes. Passouse a entender que a pena, por sua natureza, é retributiva, tem seu aspecto moral, mas sua finalidade é não só a prevenção, mas também um misto de educação e correção.

$(\ldots)$

Com o surgimento da Escola da Defesa Social, de Adolfo Prins e Filippo Grammatica, e, mais recentemente com a Nova Defesa Social, de Marc Ancel, tem-se buscado instituir um movimento de política criminal humanista fundado na ideia de que a sociedade apenas é defendida à medida que se proporciona a adaptação do condenado ao meio social (teoria ressocializadora).

Em decorrência dessa teoria ressocializadora, deve ser observado, na aplicação e execução das penas impostas, o princípio da atenuação ou compensação, assim conceituado por Alberto Silva Franco5:

O princípio da atenuação ou compensação tem seu núcleo essencial na ideia de que o cumprimento da pena na prisão não deve resumir-se exclusivamente no trancafiamento de uma pessoa em estabelecimento prisional para efeito de ser submetida a normas de segurança e de disciplina. Ao afastamento obrigatório do recluso da vida em liberdade, devem corresponder compensaçóes que visem estimulá-lo ao exercício de direitos não atingidos pela condenação, atenuando, assim, os efeitos desse afastamento, e que possibilitem à promoção de um processo de reintegração social.

Essa necessidade de ressocialização do preso tem sido reconhecida pela Jurisprudência ${ }^{6}$ :

"O regime prisional "tem por objetivo efetivar as disposiçóes da sentença ou decisão criminal” e proporcionar condições para a harmônica integração social do condenado e do internado", os quais são classificados de

5 FRANCO, Alberto Silva et al. Código penal e sua interpretaçáo jurisprudencial. $7^{a}$ ed. Sáo Paulo : Editora Revista dos Tribunais, 2001, p. 545.

6 Decisão citada por: FRANCO, Alberto Silva et al. Código penal e sua interpretaçáo jurisprudencial. $7^{\text {a }}$ ed. São Paulo : Editora Revista dos Tribunais, 2001, p. 545. 
acordo com os antecedentes e a personalidade, podendo progredir de um regime mais rigoroso para outro mais suave por um sistema de mérito em que sáo considerados requisitos objetivos e subjetivos (STJ - HC 950 Rel. Costa Lima - DJU DE 16.3.92, p. 3102).

Como se vê, a aplicação da pena e a restrição da liberdade do preso não devem resultar na restriçáo de outros direitos, uma vez que quanto maior a garantia de direitos náo atingidos pela sanção imposta, maior a possibilidade de se obter a ressocialização do preso quando ele terminar o cumprimento da pena.

Nesse sentido, a garantia do direito ao trabalho é reconhecidamente uma das melhores formas de ressocializar o ex-detento, razão pela qual a obtenção do trabalho deve ser buscada ainda durante o cumprimento da pena.

Aqui, porém, surge um questionamento: e se o preso, apesar de lhe ser garantida a possibilidade de trabalhar, não tem condições de fazê-lo em razão de ser pessoa idosa ou com deficiência?

A resposta a tal questão se pretende oferecer no próximo item.

\section{O Direito ao Trabalho ou ao Benefício Assistencial}

A Constituição Federal, norma suprema do ordenamento jurídico, estabelece entre os direitos sociais, o direito ao trabalho:

Art. 60 São direitos sociais a educação, a saúde, a alimentação, o trabalho, a moradia, o lazer, a segurança, a previdência social, a proteção à maternidade e à infância, a assistência aos desamparados, na forma desta Constituição.

Já em relação aos acusados em processos crime, a Constituição, em seu art. 5\% traz um extenso rol de direitos e garantias, dentre os quais, para este trabalho, merecem destaque os seguintes:

Art. 50 Todos são iguais perante a lei, sem distinção de qualquer natureza, garantindo-se aos brasileiros e aos estrangeiros residentes no País a inviolabilidade do direito à vida, à liberdade, à igualdade, à segurança e à propriedade, nos termos seguintes:

(...)

XXXIX - não há crime sem lei anterior que o defina, nem pena sem prévia cominação legal;

(...)

XLVI - a lei regulará a individualização da pena e adotará, entre outras, as seguintes: 

a) privação ou restrição da liberdade;
b) perda de bens;
c) multa;
d) prestação social alternativa;
e) suspensão ou interdição de direitos;
XLVII - não haverá penas:

a) de morte, salvo em caso de guerra declarada, nos termos do art. 84, XIX;
b) de caráter perpétuo;
c) de trabalhos forçados;
d) de banimento;
e) cruéis;
(...)

Assim, diante da leitura dos preceitos constitucionais acima mencionados, é possível concluir que o trabalho é um direito social garantido a todas e todos, inclusive aos que estão cumprindo penas pela prática de crimes, uma vez que para estes é expressamente vedada a pena de trabalhos forçados.

Claro que o texto constitucional permite que sejam aplicadas penas de suspensão ou interdição de direitos, mas deixa claro que o trabalho forçado não é uma opção válida, além de exigir, para a aplicação de uma pena, que ela esteja previamente estabelecida na lei para determinado crime.

Além disso, apesar de a Constituição náo trazer expresso o direito do preso ao trabalho, a Lei de Execução Penal (Lei no 7.210/1984) dedica todo um capítulo ao tema (o III). Dentre os artigos do presente capítulo, merecem destaque:

\section{CAPÍTULO III}

Do Trabalho

SEÇÃO I

Disposiçôes Gerais

Art. 28. O trabalho do condenado, como dever social e condição de dignidade humana, terá finalidade educativa e produtiva.

$\$ 1^{\circ}$ Aplicam-se à organização e aos métodos de trabalho as precauções relativas à segurança e à higiene.

$\$ 2^{\circ} \mathrm{O}$ trabalho do preso não está sujeito ao regime da Consolidaçâo das Leis do Trabalho.

Art. 29. O trabalho do preso será remunerado, mediante prévia tabela, não podendo ser inferior a $3 / 4$ (três quartos) do salário mínimo. 
$\$ 1^{\circ} \mathrm{O}$ produto da remuneração pelo trabalho deverá atender:

a) à indenização dos danos causados pelo crime, desde que determinados judicialmente e não reparados por outros meios;

b) à assistência à família;

c) a pequenas despesas pessoais;

d) ao ressarcimento ao Estado das despesas realizadas com a manutenção do condenado, em proporção a ser fixada e sem prejuízo da destinação prevista nas letras anteriores.

$\$ 2^{\circ}$ Ressalvadas outras aplicaçóes legais, será depositada a parte restante para constituição do pecúlio, em Caderneta de Poupança, que será entregue ao condenado quando posto em liberdade.

Art. 30. As tarefas executadas como prestação de serviço à comunidade não serão remuneradas.

SEÇÃO II

Do Trabalho Interno

Art. 31. O condenado à pena privativa de liberdade está obrigado ao trabalho na medida de suas aptidóes e capacidade.

Parágrafo único. Para o preso provisório, o trabalho não é obrigatório e só poderá ser executado no interior do estabelecimento.

Art. 32. Na atribuição do trabalho deverão ser levadas em conta a habilitação, a condição pessoal e as necessidades futuras do preso, bem como as oportunidades oferecidas pelo mercado.

$\$ 1^{\circ}$ Deverá ser limitado, tanto quanto possível, o artesanato sem expressão econômica, salvo nas regiôes de turismo.

$\S 2^{\circ}$ Os maiores de 60 (sessenta) anos poderáo solicitar ocupação adequada à sua idade.

$\$ 3^{\circ}$ Os doentes ou deficientes físicos somente exercerão atividades apropriadas ao seu estado.

Art. 33. A jornada normal de trabalho náo será inferior a 6 (seis) nem superior a 8 (oito) horas, com descanso nos domingos e feriados.

Parágrafo único. Poderá ser atribuído horário especial de trabalho aos presos designados para os serviços de conservação e manutenção do estabelecimento penal.

Art. 34. O trabalho poderá ser gerenciado por fundação, ou empresa pública, com autonomia administrativa, e terá por objetivo a formação profissional do condenado.

$\$ 1^{\circ}$ Nessa hipótese, incumbirá à entidade gerenciadora promover e supervisionar a produção, com critérios e métodos empresariais, encarregar-se de sua comercialização, bem como suportar despesas, inclusive 
pagamento de remuneração adequada. (Renumerado pela Lei no 10.792 , de 2003)

$\$ 2^{\circ}$ Os governos federal, estadual e municipal poderão celebrar convênio com a iniciativa privada, para implantação de oficinas de trabalho referentes a setores de apoio dos presídios. (Incluído pela Lei no 10.792 , de 2003)

Art. 35. Os órgãos da Administração Direta ou Indireta da União, Estados, Territórios, Distrito Federal e dos Municípios adquirirão, com dispensa de concorrência pública, os bens ou produtos do trabalho prisional, sempre que não for possível ou recomendável realizar-se a venda a particulares.

Parágrafo único. Todas as importâncias arrecadadas com as vendas reverterão em favor da fundação ou empresa pública a que alude o artigo anterior ou, na sua falta, do estabelecimento penal.

\section{SEÇÃO III}

\section{Do Trabalho Externo}

Art. 36. O trabalho externo será admissível para os presos em regime fechado somente em serviço ou obras públicas realizadas por órgãos da Administração Direta ou Indireta, ou entidades privadas, desde que tomadas as cautelas contra a fuga e em favor da disciplina.

$\$ 1^{\circ} \mathrm{O}$ limite máximo do número de presos será de $10 \%$ (dez por cento) do total de empregados na obra.

$\$ 2^{\circ}$ Caberá ao órgão da administração, à entidade ou à empresa empreiteira a remuneração desse trabalho.

$\$ 3^{\circ}$ A prestação de trabalho à entidade privada depende do consentimento expresso do preso.

Art. 37. A prestação de trabalho externo, a ser autorizada pela direção do estabelecimento, dependerá de aptidão, disciplina e responsabilidade, além do cumprimento mínimo de $1 / 6$ (um sexto) da pena.

Parágrafo único. Revogar-se-á a autorização de trabalho externo ao preso que vier a praticar fato definido como crime, for punido por falta grave, ou tiver comportamento contrário aos requisitos estabelecidos neste artigo.

Pela leitura do parágrafo único do art. 31, acima mencionado, pode-se chegar à conclusão de que o trabalho seria obrigatório para os presos definitivos, uma vez que o referido preceito expressamente dispóe que o trabalho não é obrigatório para os presos provisórios.

Porém, da leitura dos arts. 39 e 41, que estabelecem, respectivamente, os deveres e direitos do condenado, verifica-se que o trabalho, além de um dever, também é um direito: 
Art. 39. Constituem deveres do condenado:

(...)

V - execução do trabalho, das tarefas e das ordens recebidas;

(...)

Art. 41 - Constituem direitos do preso:

(...)

II - atribuição de trabalho e sua remuneração;

III - Previdência Social;

IV - constituição de pecúlio;

$\mathrm{V}$ - proporcionalidade na distribuição do tempo para o trabalho, o descanso e a recreação;

Além disso, o art. 41 é expresso em estabelecer que ao preso deve ser garantida a remuneração pelo trabalho executado, a Previdência Social, a possibilidade de constituição de pecúlio (economia), além da distribuição proporcional do tempo para o trabalho, descanso e recreação.

Ao interpretar todos os preceitos acima mencionados, previstos tanto na Constituição quanto na Lei de Execuçáo Penal, os Tribunais têm reconhecido o trabalho como um direito subjetivo dos condenados:

PROCESSO PENAL. HABEAS CORPUS. CRIME HEDIONDO. CONDENAÇÁO. TRABALHO EXTERNO. POSSIBILIDADE. ORDEM PARCIALMENTE CONCEDIDA. 1. A Constituiçáo Federal, o Código Penal e a Lei de Execuçáo Penal garantem ao preso o direito de trabalhar; 2 . O condenado por crime hediondo, por força dos arts. $6^{\circ}, \mathrm{CR}, 34, \$ 3^{\circ}$, CP e 36 , LEP, pode exercer atividade laboral externa, não havendo qualquer incompatibilidade desses dispositivos com o art. $2^{\circ}, \$ 1^{\circ}$, Lei $8.072 / 90 ; 3$. Ordem parcialmente concedida para que o Juízo da execuçáo analise os requisitos legais para deferimento do pedido de trabalho extramuros. (destaque nosso) (Superior Tribunal de Justiça. Habeas corpus 200400560099. Órgão Julgador: Sexta Turma. Relator Ministro Paulo Medina. DJ: 18/04/2005, p. 395)

EXECUÇÃO PENAL. HABEAS CORPUS. ART. 1, II, DA LEI N. ${ }^{\circ}$ 8.137/90, C/C OS ARTS. 11 E 12 DO MESMO DIPLOMA LEGAL. PROGRESSÃO DE REGIME. TRABALHO EXTERNO. I - Em hipóteses excepcionais, esta Corte tem concedido ao condenado em regime semi-aberto, o cumprimento da reprimenda em regime aberto, desde que não haja vaga no estabelecimento prisional adequado. $\mathrm{Na}$ hipótese dos autos, entretanto, não é possível auferir tal situação, uma vez que o impetrante se limita a meras conjecturas, sem comprovar de forma robusta e subsistente, as alegaçôes acerca de irregularidades no presídio onde deve 
ser cumprida a pena e da falta de vagas para o regime semi-aberto. Ademais, o paciente encontra-se foragido, sequer tendo iniciado a execução da pena. II - Segundo o entendimento jurisprudencial do STJ, o direito ao trabalho externo pode ser conferido ao condenado, independentemente do cumprimento de um sexto da pena, desde que estejam presentes os requisitos subjetivos, constantes do art. 37 da Lei de Execuçóes Penais, quais sejam, aptidáo, disciplina e responsabilidade. Ocorre que nem o Juízo da Execução, nem o e. Tribunal a quo, deles tratou. Dessa forma, fica esta Corte impedida de se manifestar a pedido de trabalho externo, sob pena de supressão de instância. (Precedentes.) Recurso parcialmente conhecido e, nesse ponto, desprovido. (destaque nosso). (Superior Tribunal de Justiça. Recurso ordinário em Habeas corpus 200200164758. Órgão Julgador: Quinta Turma. Relator Ministro Felix Fischer. DJ: 31/05/2004, p. 325)

PENAL. PROCESSUAL PENAL. AGRAVO EM EXECUÇÃO. DIREITO DO PRESO AO TRABALHO. INEXISTENNCIA DE VAGA. REMIÇÃO INDEPENDENTE DO TRABALHO. IMPOSSIBILIDADE. 1. Atribuiçáo de trabalho e sua remuneraçáo constituem direito do preso, nos termos do art. 41, II da Lei de Execuçáo Penal. Os dias de trabalho ou de atividade estudantil serão computados para fins de remição, segundo o art. 126 do mesmo diploma legal. 2. A remição, de acordo com entendimento do Supremo Tribunal Federal constitui expectativa de direitos, condicionada ao preenchimento de todos os requisitos legais. Assim, não há falar em remição quando não prestado o trabalho ou comprovada a freqüência em curso de ensino formal. 3. A falta de oportunidade de trabalho ou estudo no estabelecimento prisional náo importa em direito à remição independentemente do efetivo labor. Precedentes desta e. Corte. 4. Deve ser assegurado ao reeducando o direito ao trabalho, no estabelecimento prisional em que se encontra, garantindo-se, assim, a remiçáo da pena bem como a reinserçâo do indivíduo na sociedade. 5. Agravo em execução parcialmente provido. (destaque nosso). (Tribunal Regional Federal da 1a Região. Agravo em Execução Penal 201041000007567. Órgão Julgador: Terceira Turma. e-DJF1: 20/05/2011. p. 33)

Diante desse quadro, a pergunta que se pretende responder com este artigo é: e se o condenado, apesar de ter direito ao trabalho, náo consegue trabalhar por ser uma pessoa com deficiência ou por ter completado 65 anos de idade?

De acordo com o texto constitucional, a assistência social será prestada a "quem dele necessitar":

Art. 203. A assistência social será prestada a quem dela necessitar, independentemente de contribuição à seguridade social, e tem por objetivos:

I - a proteção à família, à maternidade, à infância, à adolescência e à velhice; 
II - o amparo às crianças e adolescentes carentes;

III - a promoçẫo da integração ao mercado de trabalho;

IV - a habilitação e reabilitação das pessoas portadoras de deficiência e a promoção de sua integração à vida comunitária;

$\mathrm{V}$ - a garantia de um salário mínimo de benefício mensal à pessoa portadora de deficiência e ao idoso que comprovem náo possuir meios de prover à própria manutenção ou de tê-la provida por sua família, conforme dispuser a lei.

Como se vê, segundo o artigo acima mencionado (que não exclui as pessoas que se encontram encarceradas) será garantido "um salário minimo de benefício mensal à pessoa portadora de deficiência e ao idoso que comprovem náo possuir meios de prover à própria manutenção ou de tê-la provida por sua família, conforme dispuser a lei”.

Visando regulamentar referido preceito constitucional, foi editada a Lei ${ }^{\circ}$ 8.742, de 7 de dezembro de 1993, que prevê:

Art. 20. O benefício de prestação continuada é a garantia de um saláriomínimo mensal à pessoa com deficiência e ao idoso com 65 (sessenta e cinco) anos ou mais que comprovem não possuir meios de prover a própria manutenção nem de tê-la provida por sua família. (Redação dada pela Lei no 12.435 , de 2011)

Referida lei, da mesma forma que a Constituição, também não excluiu expressamente a possibilidade de pessoas encarceradas receberem o benefício assistencial. Na verdade, ao contrário disso, trouxe expresso preceito que, aplicado por analogia, permite chegar à conclusão oposta, ou seja, que o fato de a pessoa estar recolhida num estabelecimento prisional não é impeditivo de tal recebimento:

Art. 20

(...)

$\$ 5^{\circ}$ A condição de acolhimento em instituiçóes de longa permanência não prejudica o direito do idoso ou da pessoa com deficiência ao benefício de prestação continuada. (Redação dada pela Lei no 12.435 , de 2011)

Dessa forma, o fato de uma pessoa idosa ou com deficiência estar acolhida numa instituição de longa permanência não a impede de receber o benefício assistencial, regra que também deverá ser aplicada se o requerente do benefício encontra-se recolhido em instituição prisional.

Em outras, o preceito acima mencionado deve ser aplicado por analogia às pessoas que se encontram recolhidas em estabelecimentos prisionais cumprindo pena e essa 
situação não dever ser elencada como impeditiva para a concessão do benefício assistencial.

Com isso, seria garantida a aplicação de todos os preceitos até aqui mencionados, ou seja, além de se garantir a aplicação da lei penal, com a imposição das respectivas sançóes àqueles que cometeram delitos, também seria respeitada a legislação que garante ao preso o direito ao trabalho ou, no caso de impossibilidade em razão da idade ou deficiência, o recebimento do benefício assistencial previsto no art. 203 da Constituição e regulamentado pela Lei no 8.742/1993.

Claro que existe decisão em sentido contrário:

BENEFÍCIO ASSISTENCIAL. LEI No 8.742, DE 1993. DEFICIENTE. CONDIÇÃO DE PRESO. É devido o benefício assistencial da Lei $\mathrm{n}^{\circ} 8.742$, de 1993, a deficiente incapaz para o trabalho, que não vive com seus familiares, porém somente até a data em que passou à custódia do Estado, passando a ser por este sustentado e assistido, na condição de preso. (TRF-4 - AC: 2135 SC 2008.72.99.002135-4, Relator: RÔMULO PIZZOLATTI, Data de Julgamento: 10/03/2011, Quinta Turma, Data de Publicação: D.E. 24/03/2011).

Essa decisão suscita o fato de, ao estar recolhido em estabelecimento prisional, o condenado estaria totalmente amparado pelo Estado que, nessas condiçóes, garantiria todas as suas necessidades básicas, sendo desnecessário o pagamento do benefício assistencial.

Levantamentos realizados pelo Conselho Nacional de Justiça $(\mathrm{CNJ})^{7}$, porém, indicam que as condições das instituiçóes prisionais não são aptas a garantir os direitos dos presos. Na verdade, a situação é a oposta, ou seja, é extremamente comum a violação de direitos dos presos.

Nesse aspecto, nos últimos anos, ganhou destaque na mídia nacional e internacional a situação caótica dos presídios do Estado de Espírito Santo, em especial na Casa de Custódia de Viana (Cascuvi) ${ }^{8}$, e do Estado do Maranhão, com destaque para o presídio de Pedrinhas (MA) .

Apesar desses casos terem ganho notoriedade, o certo é que todas as unidades prisionais apresentam deficiências e, desse modo, não conseguem garantir de forma adequada as necessidades básicas dos que nelas estão recolhidos.

7 Para relatórios atualizados do $\mathrm{CNJ}$ relativos à situação dos presídios, ver a página do projeto "GEOPRESÍDIOS”. Disponível em: www.cnj.jus.br/geopresidios . Acesso em: 06/03/2014.

8 VIOLAÇÓES de direitos humanos no sistema prisional do Espírito Santo. Atuação da Sociedade civil. Data: maio/2011. Disponível em: http://global.org.br/wp-content/uploads/2011/06/SistemaPrisiona1ES_2011.pdf. Acesso em: 04/02/2014.

9 PRESOS filmam decapitados em penitenciária no Maranhão; veja vídeo. Data: 07/01/2014. Disponível em: http://wwwl.folha.uol.com.br/cotidiano/2014/01/1394160-presos-filmam-decapitados-em-penitenciaria-no-maranhao-veja-video.shtml. Acesso em: 04/02/2014. 
Na prática, tal situação faz com que aos presos sejam impostas outras sançôes, além daquelas expressamente previstas na lei e aplicadas no caso concreto. Assim, ao ser sentenciado a cumprir cinco anos de reclusão em regime inicial fechado, o réu, na realidade, está sendo condenado a tal pena e, também, a um extenso rol de restriçôes aos seus direitos. $\mathrm{O}$ acesso à alimentação adequada, ao sistema de saúde, aos produtos básicos para uma higiene pessoal mínima são apenas algumas das restriçôes que, a despeito de não estarem previstas na lei, são impostas aos presos.

Assim, nessa situação, negar a concessáo do benefício assistencial ao preso idoso ou com deficiência não se justifica e demonstra um total desconhecimento da realidade dos presídios e unidades prisionais brasileiras.

Claro que, em algumas situaçóes, o benefício assistencial não deverá ser pago aos condenados que cumprem penas, o que se analisará no próximo item.

\section{Aspectos Práticos da Concessão do Benefício Assistencial aos Presos}

Evidente que, em alguns casos, não será possível a concessão do benefício assistencial às pessoas que se encontram recolhidas em unidades prisionais.

A primeira das exceçóes, que decorre da própria lei, diz respeito aos casos em que é cabível a concessão de algum benefício previdenciário ao preso ou aos seus familiares:

Art. 20.

(...)

$\$ 4^{\circ}$ O benefício de que trata este artigo não pode ser acumulado pelo beneficiário com qualquer outro no âmbito da seguridade social ou de outro regime, salvo os da assistência médica e da pensão especial de natureza indenizatória. (Redação dada pela Lei no 12.435 , de 2011)

Assim, se a pessoa presa preenche os requisitos legais para receber um benefício previdenciário, como auxílio-doença, alguma espécie de aposentadoria ou mesmo o auxílio reclusão para os seus dependentes, é incabível o pagamento do benefício assistencial.

Além disso, também não será devido o benefício assistencial se não estiverem preenchidos os demais requisitos objetivos previstos na lei, ou seja, se o condenado não tiver completado os 65 anos de idade ou, ainda, não for considerado deficiente.

Também não deverá ser concedido o benefício assistencial se a família do preso tiver condiçóes de garantir a sua subsistência, mesmo que ele tenha 65 anos de idade ou mais, ou seja pessoa com deficiência.

Surge a dúvida, porém, quanto à renda da família, diante da decisão do Supremo Tribunal Federal que considerou inconstitucionais os preceitos que estabeleciam o limite 
de $1 / 4$ do salário-mínimo como renda mensal per capita máxima para a concessão do benefício assistencial ${ }^{10}$ :

STF declara inconstitucional critério para concessão de benefício assistencial a idoso

Por maioria de votos, o Plenário do Supremo Tribunal Federal (STF) confirmou nesta quinta-feira (18) a inconstitucionalidade do parágrafo $3^{\circ}$ do artigo 20 da Lei Orgânica da Assistência Social (Lei 8.742/1993) que prevê como critério para a concessão de benefício a idosos ou deficientes a renda familiar mensal per capita inferior a um quarto do salário mínimo, por considerar que esse critério está defasado para caracterizar a situação de miserabilidade. Foi declarada também a inconstitucionalidade do parágrafo único do artigo 34 da Lei 10.471/2003 (Estatuto do Idoso).

\section{Recursos Extraordinários}

A decisão de hoje ocorreu na Reclamação (RCL) 4374, no mesmo sentido do entendimento já firmado pelo Plenário na sessão de ontem, quando a Corte julgou inconstitucionais os dois dispositivos ao analisar os Recursos Extraordinários (REs) 567985 e 580963 , ambos com repercussão geral. Porém, o Plenário não pronunciou a nulidade das regras. $\mathrm{O}$ ministro Gilmar Mendes propôs a fixação de prazo para que o Congresso Nacional elaborasse nova regulamentação sobre a matéria, mantendo-se a validade das regras atuais até o dia 31 de dezembro de 2015, mas essa proposta não alcançou a adesão de dois terços dos ministros (quórum para modulação). Apenas cinco ministros se posicionaram pela modulação dos efeitos da decisão (Gilmar Mendes, Rosa Weber, Luiz Fux, Cármen Lúcia e Celso de Mello).

Da mesma forma, o Supremo Tribunal Federal também decidiu pela inconstitucionalidade do preceito que exclui do cálculo da renda per capita o benefício assistencial anteriormente concedido a outra pessoa idosa, ao julgar o Recurso Extraordinário no 580963:

O Tribunal, por maioria, negou provimento ao recurso extraordinário e declarou incidenter tantum a inconstitucionalidade do parágrafo único do art. 34 da Lei no 10.741/03 (Estatuto do idoso), vencidos os Ministros Dias Toffoli, Ricardo Lewandowski e Marco Aurélio, que davam provimento ao recurso. Não foi alcançado o quorum de $2 / 3$ para modulação dos efeitos da decisão para que a norma tivesse validade até 31/12/2015. Votaram pela modulação os Ministros Gilmar Mendes, Rosa Weber,

10 STF declara inconstitucional critério para concessão de benefício assistencial a idoso. Data: 18/04/2013. Disponível em: http://www.stf.jus.br/portal/cms/verNoticiaDetalhe.asp?idConteudo=236354. Acesso em: 06/03/2014. 
Luiz Fux, Cármen Lúcia e Celso de Mello. Votaram contra a modulação os Ministros Teori Zavascki, Dias Toffoli, Ricardo Lewandowski e Joaquim Barbosa (Presidente). O Ministro Marco Aurélio absteve-se de votar quanto à modulaçáo. $\mathrm{O}$ Ministro Teori Zavascki reajustou seu voto proferido na assentada anterior. Plenário, 18.04.2013. (STF, Recurso Extraordinário no 580.693/PR, Relator Ministro Gilmar Mendes. Decisão: 18/04/2013. Data de publicação: DJE 14/11/2013 - ATA No 174/2013. DJE no 225, divulgado em 13/11/2013).

Diante de tais decisóes, a solução que tem sido adotada é a análise individualizada de cada caso, com o fim de verificar se a família do requerente tem ou não condiçóes de garantir a sua subsistência:

PREVIDENCIÁRIO. BENEFÍCIO ASSISTENCIAL. IDADE E ESTADO DE MISERABILIDADE COMPROVADOS. CONCESSÃO DO BENEFÍCIO NA VIA ADMINISTRATIVA. EXTINÇÃO DO FEITO COM JULGAMENTO DO MÉRITO QUANTO AO PERÍODO POSTERIOR À CONCESSÃO ADMINISTRATIVA. PROCEDÊNCIA DO PEDIDO QUANTO AO PERÍODO ANTERIOR. SENTENÇA REFORMADA.

1. Para fins de composição da renda familiar, entendo que não pode ser computado o benefício previdenciário de valor mínimo percebido por idoso, com 65 anos ou mais, considerado necessário a sua sobrevivência digna (Aplicação por analogia do parágrafo único do art. 34 da Lei n 10.741/2003). 2. CPC. 2. Inexistindo critério numérico atual tido por constitucional pelo STF (Declaração de Inconstitucionalidade do critério de $1 / 4$ do salário mínimo, previsto no $\$ 3^{\circ}$ do art. 20 da LOAS - Rcl no 4374), inviável o indeferimento do benefício pelo simples fato de a renda per capita ser superior a $1 / 4$ do salário mínimo. Cuidando-se de renda que pouco supera esse parâmetro e consideradas as restantes circunstâncias do caso concreto, tenho por verificada a situaçấo de miserabilidade. 3. Como houve a concessão administrativa do benefício assistencial em favor do autor no curso desta ação, é de ser julgado extinto o feito com julgamento do mérito por reconhecimento parcial do pedido, com relação ao período posterior à concessão administrativa, nos termos do art. 269, inc. II, do CPC. 4. Preenchidos os requisitos legais para a obtenção do benefício, quais sejam, a idade e o estado de miserabilidade, faz jus a parte autora ao pagamento das parcelas atrasadas desde a data do requerimento até a data do deferimento do benefício na vida administrativa. (TRF 4a Região, Apelação Cível no 0020076-52.2012.404.9999/SC, Data da Decisão: 05/06/2013, Órgão Julgador: Sexta Turma, Publicação D.E. 17/06/2013, Relator Desembargador NÉFI CORDEIRO, Relator para o Acórdão Desembargador JOÃO BATISTA PINTO SILVEIRA)

A mesma soluçáo deve ser adotada no caso de requerente que se encontre preso cumprindo pena pela prática de crime. 
Assim, quando solicitada a concessão do benefício assistencial, a única opção existente é que a situação de cada preso seja analisada individualmente, para o fim de verificar se, no caso concreto, a família do condenado tem condiçôes ou não de garantir sua subsistência, mesmo ele estando recolhido em estabelecimento prisional, diante da notória ineficiência e carência do sistema prisional brasileiro.

\section{Conclusões}

O grau de desenvolvimento de um país pode ser apurado a partir da análise da forma pela qual ele trata os seus cidadãos presos.

Claro que, diante da prática de um crime, os seus responsáveis devem ser punidos, com a imposição das sançóes previstas na lei, mas a pena não pode ser ampliada a ponto de impor ao condenado restriçóes a direitos que não encontrem amparo legal.

No presente caso, a discussão gravita em torno da possibilidade (ou não) de os presos em estabelecimentos prisionais receberem o benefício assistencial previsto no art. 203 da Constituição, nos casos em que em razão da idade (65 anos de idade ou mais) ou de deficiência não têm condiçóes de exercer o seu direito ao trabalho.

Após apresentar algumas consideraçóes sobre o direito de punir do Estado e quais devem ser os objetivos da pena, defende-se que o benefício assistencial deve ser pago a tais presos, uma vez que a imposição da pena não deve resultar na impossibilidade de recebimento de tal amparo social.

A tese contrária de que seria impossível o pagamento do benefício assistencial em razão de o preso estar recolhido em estabelecimento prisional e, portanto, com todas as suas necessidades básicas atendidas pelo Estado não deve prosperar, pois parte de uma premissa falsa de que os presídios e unidades prisionais brasileiros têm condiçóes de garantir os direitos das pessoas idosas e com deficiência que neles cumprem penas.

A realidade é muito diferente do previsto na lei, pois muitas vezes os presídios e as unidades prisionais são centros de violaçóes de direitos humanos e não locais em que eles são respeitados.

O que se espera é que o presente artigo permita uma maior reflexão do tema, inclusive com a pacificação no sentido de que o benefício assistencial é devido a todas as pessoas idosas (com 65 anos de idade ou mais) ou com deficiência que não tenham condições de prover a própria subsistência ou tê-la provida por sua família, estejam tais pessoas presas ou não.

Afinal, o fato de estar presa para o cumprimento da pena não retira da pessoa a condição de cidadã, titular de direitos, que deve ser tratada com respeito e consideração. 


\section{Referências}

BECCARIA, Cesare. Dos delitos e das penas. São Paulo: Martin Claret, 2000, p. 19.

FRANCO, Alberto Silva et al. Código penal e sua interpretação jurisprudencial. $7^{\mathrm{a}} \mathrm{ed}$. São Paulo: Editora Revista dos Tribunais, 2001, p. 545.

GEOPRESÍDIOS. Disponível em: www.cnj.jus.br/geopresidios. Acesso em: 06/03/2014.

MIRABETE, Julio Fabbrini. Manual de direito penal, v. 1, Parte Geral. 6a ed. São Paulo: Atlas, 1991, p. 234-235.

PRESOS filmam decapitados em penitenciária no Maranháo; veja vídeo. Data: 07/01/2014. Disponível em: http://www1.folha.uol.com.br/cotidiano/2014/01/ 1394160-presos-filmam-decapitados-em-penitenciaria-no-maranhao-veja-video. shtml. Acesso em: 04/02/2014.

STF declara inconstitucional critério para concessão de benefício assistencial a idoso. Data: 18/04/2013. Disponível em: http://www.stf.jus.br/portal/cms/verNoticiaDetalhe.asp?idConteudo=236354. Acesso em: 06/03/2014.

VIOLAÇÕES de direitos humanos no sistema prisional do Espírito Santo. Atuação da Sociedade civil. Data: maio/2011. Disponível em: http://global.org.br/wp-content/ uploads/2011/06/SistemaPrisionalES_2011.pdf. Acesso em: 04/02/2014.

ZAFFARONI, Eugenio Raul. PIERANGELI, José Henrique. Manual de direito penal brasileiro. Vol. 1. Parte geral. 6. ed. Sáo Paulo : Editora Revista dos Tribunais, 2006, p. 63. 